\title{
Universities' Websites: Disclosure Practices and the Revelation of Financial Information
}

\author{
Isabel Gallego. Universidad de Salamanca, Spain. igallego@usal.es \\ Isabel-María García. Universidad de Salamanca, Spain. lajefa@usal.es \\ Luís Rodríguez. Universidad de Salamanca, Spain. lrodomin@usal.es
}

\begin{abstract}
Despite the social importance of universities and their significance as receivers of public funds, hardly any research exists about their disclosure of financial information. The scarce research that has been done has focused on countries such as the United States, New Zealand, Austria, the United Kingdom and Norway. In addition, the Internet is used widely on behalf of public bodies as a way to improve their relations with citizens, through greater disclosure of information and the possibility of doing administrative business and paperwork online. Considering both topics, this work has a twofold objective: (1) to analyse the disclosure of information revealed online by Spanish universities, focusing on several issues, such as financial information, corporate governance, social responsibility and strategy, teaching and research activities, etc.; and (2) to observe the factors that explain the disclosure of financial information through Spanish universities' websites, focusing mainly on size, leverage, university profitability, governance, type of university, research orientation, age of the university and its internationality etc. This study takes into account the whole population of Spanish universities (70 universities: 48 public and 22 private). The findings obtained emphasize that university websites mainly disclose information on teaching and research activities and on governing bodies; to a lesser extent, they reveal information on their social responsibility and strategic aspects; and finally, the volume of financial information disclosed remains quite small, mainly including their budgets. Furthermore, the universities with lower levels of leverage disclose more information online, whereas those with higher volumes of debt are more reluctant to reveal their internal situation on the Internet.
\end{abstract}

Key words: Financial information, universities, web pages, explanatory factors, leverage. 


\section{INTRODUCTION}

The Bricall Report (2000: 403) underscores the increasing demand for information by different stakeholders concerning the activities undertaken by universities in Spain, especially the information related to annual accounts. This demand has to cope with several drawbacks: the information is revealed in a delayed way and is not widely accessible to global stakeholders. Moreover, is it not disclosed in any public office and the report made by the public body charged with monitoring their finances -the "Account Court"- is issued two years subsequent to the end of the economic year. This demand for more information is common to different countries, such as the United States (Kass, 2005) where universities are more scrutinized and there is a wide discussion about highereducation costs (Hechinger, 2006) or Australia (Nelson et al., 1997), where major changes have been required in the last decade.

The increase in global and financial information required of universities nowadays may have its origin in the international globalisation process, which requires universities to become management units in search of new means of financing, interacting with public and private agents. At the same time, there is a current trend in society toward greater openness and transparency (Kass, 2005), both in the private and state contexts. Universities receive a high amount of public funds and undertake a considerable process of resource allocations. Owing to the public origin of the funds, universities have to be especially rigorous in assigning funds to activities. The process of resource allocation in public bodies (like universities) should be particularly transparent. In this vein, Angluin and Scapen (2000) have highlighted a close relationship between transparency and perceived fairness in resource allocation. Therefore, the failure of many universities to provide information about their objectives and figures makes it difficult for interest groups to make informed judgements about the success of the universities in meeting their objectives and budgets, as well as obtain an overall perspective of university affairs (Nelson et al., 1997: 43).

Also, the convergence program derived from the Bologna Declaration in Europe has doubtlessly influenced this process. According to Cañibano (2008: 590): "this process demands the adoption of a single comprehensive and comparable system of degrees across Europe that improves the employability of European citizens and improves the international competitiveness of the European education system". This convergence process will finish in 2010; in Spain, the Universities Law in 2001 (modified in October 
2007) ordered the full integration of the Spanish higher education system into the European Higher Education Area.

This Law establishes that "there exists a need to improve the quality of university systems, through a culture of evaluation of university services". Murias et al. (2008) argue two main reasons for this: the increase in competition among universities in order to recruit students and the new dynamism in the financing of these institutions. ANECA ${ }^{1}$ (2008) also underlines the importance of disclosing information online in order to achieve quality certifications (particularly in doctoral studies).

These information requirements, both those imposed by law and those derived from an increase in demand by stakeholders, justify the need to examine the disclosure of information by Spanish universities, considering digital information. In this vein, the providing of electronic information implies the use of information technologies to simplify the interactions between universities and those demanding information. Together with the advantages deriving from Internet usage, there is a greater scope of information distribution and consequently a larger audience for the information revealed.

Nowadays, most studies on the disclosure of financial information in universities have focused on surveys and interviews. However, hardly any previous research has been carried out based on data disclosed on the Internet, which is a potential disclosure mechanism that has many advantages (for instance, the public can access the information fast and easily). In this sense, Buenadicha et al. (2001) have analysed issues of accessibility, speed and navigability in Spanish universities from a descriptive perspective, although they do not consider financial issues. This shortage of information also occurs in other countries. For example, Nelson et al. (1997) and Angluin and Scapens (2000) have underscored the lack of financial reviews in Australian and UK universities, showing that most universities reveal only sparse or descriptive information, with difficult access to specific financial information. Instead of resorting to surveys and consulting financial departments, this work offers an alternative perspective and attempts to analyse the accessibility of this information to the general public, through the Internet.

Unlike previous studies, here we focus not only on the financial information provided by Spanish universities on their websites, but also take into consideration other types of information that can also be disclosed on the Internet, such as the universities'

\footnotetext{
${ }^{1}$ ANECA (National Agency for Quality Evaluation and Accreditation) is the public agency which evaluates the standard of quality of universities in Spain.
} 
sustainable behaviour, corporate governance bodies, etc. At the same time, this work analyses how several variables -such as size, leverage, universities' profitability, growthreduction of students, age/tradition, type of university, internationality, etc.- can influence this disclosure.

Therefore, we have undertaken this research taking into consideration that universities, as institutional receptors of public funds, should implement a policy of transparency and disclosure of activities financed by those funds and that websites can be an appropriate tool to implement this policy. We contribute to previous literature by studying the degree of utilization of websites by Spanish universities in order to meet this transparency policy and by analysing which factors influence the achievement of a higher economic-financial transparency in the disclosure online.

More specifically, this research has a dual objective: (1) to analyse the disclosure of information issued by Spanish universities on their websites, considering the importance of the Internet as a communication medium widespread in other contexts of Public Administration and corporations; and (2) to study the factors that may partially explain the disclosure of financial information on their websites. We are particularly interested in verifying the effect of several features such as size, leverage, profitability, growth of students, age / tradition, type of university, internationality, etc. on this disclosure. Our study considers the whole set of Spanish universities, which involves 70 universities (48 public and 22 private).

Our findings emphasize the priority use of the Internet as a way to disclose teaching and research activities, as well as to monitor university organs. Nevertheless, the disclosure of financial information does not seem to be a priority for universities. The low extent of financial revelation is a process common to universities with different sizes, profitability, types, research orientation and internationality. In addition, an inverse relationship between leverage and financial disclosure is detected, thereby suggesting that those universities with a lower degree of debt use their websites to reveal their greater degree of financial independence, while those universities more in debt are reluctant to disclose internal financial information.

The findings obtained for Spanish universities can be regarded as useful and interesting for other countries. We are witnessing a period in which one of the most challeging aims in universities is related to differentiation. Students will choose their degrees and universities based on the knowledge they have about them; hence, the disclosure of information through the Internet can be the most effective medium for 
people from different countries to have access to all the information provided by universities so they can choose where to study. As several studies have evidenced for universities from different countries (Buenadicha et al., 2001; Nelson et al., 1997; Angluin and Scapens, 2000), revelation of information on universities' websites worldwide is scarce, sometimes with a descriptive nature, and with difficulties involved in locating some of it (such as financial information). Therefore, any kind of disclosure of information can help to alleviate this situation and can be considered as a role model by the remaining universities worldwide.

This work is structured as follows. Section 2 focuses on the use of the Internet to reveal information by universities. In Section 3, several factors which influence the disclosure of financial information by universities are described, and the research hypotheses are stated. Section 4 explains the methods used to test the hypotheses, especially the disclosure index and the model estimated. Section 5 contains our findings and Section 6 summarises and concludes.

\section{FINANCIAL INFORMATION IN UNIVERSITIES: USE OF THE INTERNET}

According to Gordon et al. (2002), financial information is subject to many interpretations, and the information provided in financial statements can be used by different groups of stakeholders to make decisions on corporations. In the same sense, in 1999, the Government Accounting Standards Board (GASB) issued its own opinion about the objectives of financial information, concluding that there are not many differences between companies and public entities, like universities, as regards the objectives of such information. In its own words, as regards the objectives of financial reporting for government sector entities, these institutions "appeared to cross the bridge from decisionmaking to accountability by declaring that while governmental financial reporting should provide information for decision-making, the paramount objective is accountability" (GASB, 1999).

Given that the objectives of financial information are reasonably similar, the following stage is to establish who can be considered as users of universities' financial reports. In this vein, Engstrom and Fountain (1989) and Coy et al. (1997) have identified some groups of users interested in the financial information provided by universities: internal campus-based citizens (senior manager, support staff, academics), sister organizations (employees of other tertiary education institutions), elected and appointed representatives (board members, government and regulators), resource providers (suppliers and lenders, donors and sponsors, professional associations), external citizens 
(voters and taxpayers, advisers and consultants) and analysts and media (researchers, journalists).

With regard to the information that universities should provide, several studies (Gordon et al., 1997; Nelson et al., 1997; Engstrom and Fountain, 1989; Fisher and Gordon, 1991; Cave et al., 1997; Coy and Goh, 1995; Coy et al., 2001) identify disclosures about teaching, research, service efforts and accomplishments, and resource and overhead allocations; this information would advance colleges' and universities' annual reporting towards a public accountability perspective. Also, this information can be provided in different ways: formal and informal, routine and ad hoc, written, spoken, electronic, and other media. Some previous studies (e.g. Nelson et al., 1997; Angluin and Scapens, 2000) have stressed the lack of financial reviews in Australian and UK universities, showing that most universities reveal only sparse or descriptive information, with difficult access to specific financial information.

Previous research undertaken on this topic in different countries has generally used surveys or interviews to obtain financial and other types of information, as, for instance, Pettersen and Solstad (2007), for Norwegian universities; Fisher et al. (2004) and Gordon et al. (2002) for universities in the United States, Angluin and Scapens (2000) for universities in the United Kingdom, and Nelson et al. (1997) for Australian universities. In addition, there is scarce literature in which the data have been obtained through the Internet; in this line, Buenadicha et al. (2001) and Olsina et al. (1999) have analysed issues of accessibility, speed and navigability, without considering financial aspects.

In other areas of the public administration, the use of the Internet has overcome many of the technical barriers which made a fluid relationship between citizens and government more difficult. It also allows more detailed information to be presented, an increase in the frequency and timeliness of the information provided and the reduction of printing and distribution costs (Pina et al., 2007). Information technologies can be used to simplify and improve the transactions between governments and other agents (Justice et al., 2006), changing both the provision of public services and the broader field of interactions between citizens and governments (Torres et al., 2005).

Compared to traditional printed reports, in the business field the Internet offers many more opportunities to communicate corporate information and allows a wealth of up-todate, unofficial, critical and alternative channels of accounting information to compete with the official channel (Paisey and Paisey, 2006). For example, the Internet is enhancing interactivity as well as providing enhanced information delivery systems, not 
available just few years ago (Ihator, 2001). Due to the advantages and opportunities the Internet provides (Gandía and Andrés, 2005), although recent, the disclosure of online information has shown dramatic growth according to several studies, such as Petravick and Guillet (1998), Gray and Debreceny (1997) in the United States; Craven and Marston (1999) in the United Kingdom; Hedlin (1999) in Sweden; and Gallego-Álvarez et al. (2008) in Spain.

In a similar way to what occurs with other administrative bodies and corporations, it is worth emphasizing the important advantage of the transfer of information through the Internet in the context of Higher Education, because the distribution of information is undertaken in real time, with frequent updates and with a very competitive cost in comparison to other publication media. Spain's support for universities' displaying their financial information and other types of information on the Internet is linked to the arguments developed in the previous literature for global administration, especially taking into consideration that the European Union backs a knowledge-based society and a European Higher Education Area, where universities play an essential role (European Commission, 2003).

\section{FACTORS BEHIND THE DISCLOSURE OF FINANCIAL INFORMATION BY UNIVERSITIES. RESEARCH HYPOTHESES}

In universities' disclosure of financial information, several factors which have been analysed in previous studies on public institutions can act as relevant drivers, , such as institution size, leverage, university profitability, public versus private university and governance.

\section{Institution size}

Organisational size has been one of the variables most used in order to explain the disclosure of information. In the business context, and according to Giner (1995), one of the main reasons justifying the disclosure of corporate information is the need to keep adequate links with capital suppliers, in order to obtain financing under the best conditions.

From the perspective of a cost-benefit analysis, the costs of preparing and disseminating information on the Internet are likely to be unrelated to corporate size (Larrán and Giner, 2002; Bonsón and Escobar, 2004). Nevertheless, the potential benefits 
will be greater for larger-sized corporations, since there is a direct relationship between agency $\operatorname{costs}^{2}$ and disclosure benefits, as well as other aspects.

Taking into account these arguments, most previous research has found that corporate size has a positive influence on the amount of voluntary information disclosed on websites (Craven and Marston, 1999; Oyelere et al., 2003; Marston and Polei, 2004; Bonsón and Escobar, 2004; Lim et al., 2007; Boesso and Kumar, 2007) and on webpage navigability (Bonsón-Ponte et al., 2008). However, less frequently, other studies have found exceptions to the direct relationship by showing its validity only up to a certain level of size, which would exclude quoted companies in Germany (Pirchegger and Wagenhofer, 1999: 392), whereas several works do not find a statistically significant relationship, such as Khanna et al. (2004) or Ortiz and Clavel (2006), for European multinationals listed on the NYSE.

Within the public sector, size was found not to be a predictor of internet financial reporting amongst local, regional and national authorities (Baber, 1993; Evans and Patton, 1987; Christiaens, 1999; Laswad et al., 2005), although previous studies had found a positive association (Chow and Wong-Boren, 1987). In universities, Gordon et al. (2002) found that size is significant in explaining the total extent of disclosure.

Therefore, taking into accounting the different positions and the theoretical arguments, we have established the following hypothesis:

H1: Large universities disclose a greater amount of financial information on their websites compared to smaller universities.

Many previous studies have used total assets, sales and market capitalization to measure corporate size. Logically, as Gordon et al. (2002) argue, market capitalization is not a measurable value for universities. In universities, an appropriate measure of size could be the number of students, and that will be used in this study.

\section{Leverage}

The level of leverage constitutes another factor associated with a larger amount of disclosed information from the agency theory perspective (also employed to argue and

\footnotetext{
${ }^{2}$ From the agency theory perspective, the disclosure of corporate information diminishes the agency costs which stem from the conflicts of interests between managers and shareholders, and between managers and debtholders. Thus, the information which is provided can be useful for owners and managers in the decision-making process, and it can work as a system for control by shareholders and other stakeholders over managerial activities
} 
develop hypothesis $\mathrm{H} 1$ regarding size), especially as a result of conflicts stemming from the leverage. In this sense, companies with more debt have greater agency costs, because there is a possibility of transference of wealth from debtholders to stockholders. By increasing the amount of information disclosed, corporations can reduce their agency costs and any possible conflicts of interest between owners and creditors. In this respect, by analysing the influence of agency theory, several studies have found a positive effect of leverage on the amount of information revealed voluntarily (for example, Giner et al., 2003; Xiao et al., 2004; Prencipe, 2004; Alvarez, 2007), whereas other works do not find a statistically significant relationship (Giner, 1997; Oyelere et al., 2003; Gul and Leung, 2004).

Within the public sector: "the use of debt to finance public activities provides an incentive for political managers to reduce the cost of debt" (Zimmerman, 1977). This can be achieved by disclosing information that facilitates monitoring by creditors. Laswad et al. (2005) find a positive association between leverage and the voluntary use of internet financial reporting. In the university context, Gordon et al. (2002) conclude that leverage as measured by a debt to equity ratio was not associated with a higher level of disclosure.

According to the previous arguments mainly for the business context, the following hypothesis has been established:

H2: Universities with higher leverage disclose a greater volume of financial information on their websites, compared to low-leveraged universities

\section{University profitability}

The link between profitability and disclosure is especially complex. The main disclosure theories tend to indicate that there is a positive relationship. In accordance with the Agency Theory for the business context, the managers of profitable companies use information to obtain personal advantages, such as ensuring the stability of their positions and increasing their levels of compensation.

From the perspective of the Signalling Theory, profitability can be considered an indicator of the quality of the investment. Therefore, if a high level of profitability is achieved, there will be a greater incentive to disclose information and reduce the risk of being viewed negatively by stakeholders. In addition, the Political Costs Theory supports the disclosure of voluntary information, so as to justify the returns and public funds obtained. 
Economic wealth or profitability in institutions has been frequently used in previous studies on the public sector. Christiaens (1999) and Laswad et al. (2005) argue a positive link with an increase in the disclosure of information for municipalities because it implies a signal of management quality as well as the interests of stakeholders. In the same way, the largest and most profitable universities are more visible and more highly scrutinized, so they are more pressured to reveal information.

Consequently, the following hypothesis has been formulated:

H3: Universities with great profitability will disclose a larger level of financial information on their websites, compared to universities with a lower degree of economic profitability

\section{Public versus private universities}

According to Kurtenbach and Roberts (1994:230), public institutions have to cope with higher political costs in comparison to private corporations, due to the high number of constituents -taxpayers, the legislature and assorted politicians- to which they are responsible. Private institutions, however, are not as subject to these political costs. As a consequence, Gordon et al. (2002) indicate that "when holding all their factors constant, one would expect public institutions to make more extensive disclosures consistent with their multifaceted stewardship roles".

Based on previous research, we have stated the following hypothesis:

H4: Public universities will disclose a higher volume of financial information on their websites, compared to private universities

\section{Governance}

Another variable which should be considered in order to evaluate the financial information revealed by universities online is the size and composition of their management bodies, which usually comprise the president or vice-chancellor and his or her team. This team may be formed by people from different nationalities, gender and experience, which will enrich the team in their decision-takings. Along this line, Ingram (1998: 12) recommends that "the boards should be increased to facilitate improved trusteeship", on the basis of Moisan (1992: 10)'s idea: "that the general effectiveness of a board was influenced by its size". 
By considering previous works, Gordon et al. (2002) also find that bigger boards are consistent with a positive relationship with board size and the level of disclosure of financial information.

According to theoretical arguments, we have formulated the following hypothesis:

H5: Universities with more members in their management bodies disclose more financial information on their websites than universities with fewer members

\section{Age of the universities}

Another factor that can influence the degree of disclosure of overall and financial information in universities has to do with the age of the universities. Along this line, Banks et al. (1997) show that "the established universities tended to have better quality disclosure than new universities in the categories of service performance and financial performance", for universities in England, Wales and Northern Ireland.

Murias et al. (2007) obtained similar findings for the Spanish public university system, with a higher score for older universities compared to new universities. The reasons for this situation are related to the fact that research groups have had longer to establish themselves and consolidate their research in the older institutions. Moreover, these centres have tended to have -at least up until recently- very considerable numbers of students and this has meant that they have found it necessary to progressively provide student accommodation, libraries and other services. Furthermore, many modern universities have been founded in areas in which older institutions already existed and, in some cases, the creation of these more recent centres has been the result of an excision from a university that already existed.

Therefore, considering previous studies, we propose the following research hypothesis:

H6: Older universities disclose more financial information on their websites than younger universities

\section{Internationality of the university}

Currently, the importance of internationality within universities has been particularly stressed. According to Sporn (1999: 103), the recent global, competitive environmental forces have created unprecedented challenges for universities, so that the borders of universities have opened in new ways for their services and products. Cross border 
education (that is, internationalization), with the consequent requirements for structural and cultural adaptions, is pervasive and an inescapable reality on a worldwide basis.

Both in America and in Europe, there is a clear call for internationalization. For instance, the American Council on Education's Commission on International Education (1995) states that higher education institutions must become -in a genuine senseinstitutions without boundaries if the nations and their people are to prosper in the environment of the new century. In Europe, the need to internationalize has led to the implementation of the ERASMUS, CAMETT and TEMPUS programs, for example, and high priority has been given to academic international mobility of students and faculty (Sporn, 1999).

In this context, a higher level of information should be disclosed by universities in order to recruit more foreign students, for whom universities' websites will be the main source of knowledge about the universities' activities and services, and financial condition. Therefore, websites will become a relevant tool for disclosing activities and for promoting the university internationally.

Consequently, we test the following hypothesis:

H7: More international universities disclose more financial information on their websites compared to more local universities

\section{Other explanatory factors}

\section{Type of university}

Given the increasing demand for technical degrees on behalf of students (CRUE, 2008), the universities with a strong presence of this kind of degree could use their websites as an adequate mechanism for promoting them and facilitating greater knowledge in the national and international spheres.

As a consequence, a higher degree of disclosure on global and financial information is expected for this type of university.

\section{Orientation towards research}

Universities play an essential role in society as producers and transmitters of knowledge. In recent years, the discussion about whether universities can encompass a third mission of economic development, in addition to research and teaching, has received growing attention (Mansfield, 1995; Leydesdorff and Meyer, 2003). Industry- 
research collaborations are extremely important mechanisms for generating technological spillovers and currently there is an increased level of academic commercial activities, such as patenting and licensing, and generation of spin-out companies (Shane, 2004; Friedman and Silberman, 2003). At the same time, many governments have implemented an increasing range of policies encouraging the involvement of universities in technology transfer.

In this context, websites are a key mechanism for disclosing the activities undertaken in research and development, technology and transference of their results, as well as their goals and successes (patents, R\&D projects subsidized by public funds, etc.), in order to promote that university, reinforce the score obtained in different lists and obtain a higher volume of funds.

Therefore, we expect a positive association between the orientation towards research in universities and the disclosure of financial information.

\section{Complexity of the university}

The complexity of a university, referring to the number of faculties the university comprises, can affect the design and navigability of its website, in order to facilitate the search for information and to move users to their faculties through links, maps, etc. Also, the larger the university (with many faculties), the larger the amount of potential contents which can be revealed on the Internet.

On the contrary, it is also likely that the main website may lose its importance in complex universities, in favour of their faculties' own websites. Consequently, some kind of relationship is expected between complexity and disclosure.

\section{Variation in student numbers}

A growth or a decrease in the number of students in a university may influence their needs of disclosure, for instance, by using the Internet. In the case of a significant reduction in the number of students, websites can be used as a platform to recruit new students intensely. Also, this objective involves the creation of a policy framework that encourages universities to meet community and students needs by diversifying their course offerings and providing enhanced levels of information on the nature and quality of these courses for prospective students.

Therefore, we expect a positive sign in the relationship between the decrease in the number of students and disclosure of information. 


\section{RESEARCH DESIGN}

\section{Population}

In order to achieve the objectives established for the current study, the whole set of Spanish universities was selected as our target population. We chose this population because of our interest in broadening and generalising the results obtained in previous studies focused on the analysis of the explanatory factors which influence the volume of financial information disclosed (e.g. Gordon et al., 2002). Also, the selection considers the advantage of the availability of information through the Internet, thereby overcoming the limitations of previous studies, which have been based on surveys or personal interviews (e.g. Pettersen and Solstad, 2007; Fisher et al., 2004; Gordon et al., 2002).

Finally, the population analysed corresponds to 70 Spanish universities, 48 of which are public universities and 22 are private universities. After selecting the sample, we carried out a content analysis of the universities' websites.

\section{Content analysis: Creating a Disclosure Index}

In order to perform the analysis, we created a disclosure index. Creating this type of index is a branch of content analysis and one of the main techniques used to study the information provided by public and private institutions (Ortiz and Clavel, 2006). Thus, the disclosure index is one of the main ways of evaluating the informative transparency of public and private institutions (García-Meca and Martínez, 2004; Bonsón and Escobar, 2004). Our sources of factors and items used to create the disclosure index are related to two typologies of previous studies: firstly, descriptive studies referring to the disclosure of global and financial information on behalf of universities worldwide; and secondly, we complement these items with those applied in the revelation of information in other corporate contexts, such as quoted companies or civil services.

To create the index, we initially considered several descriptive studies which refer to the amount of information provided by universities on their websites; for instance, Middleton et al. (1999) analyse visibility and Lawrence and Giles (1999) study accessibility. Another widely analysed issue is usability (Badre, 2002; Dustin et al., 2002; Chandler and Hyatt, 2003; Graham, 2002). Other impact factors are analysed by Smith and Thelwal (2002). However, none of these works have focused on financial information as the research objective. 
In addition to these studies, we have also analysed several descriptive studies which analyse the amount of information provided by companies on their websites, in different countries such as the United States (Ettredge et al., 2001), Germany (Marston and Polei, 2004), Austria (Pirchegger and Wagenhofer, 1999), Denmark (Petersen and Planborg, 2006) and Spain (Larrán and Giner, 2002). These studies focus on verifying a set of issues in the disclosed information on websites, using binary values (1): presence of the information sought; $(0)$ : absence of the information sought. Then, the values obtained are aggregated and, where appropriate, weighted.

After that revision, and considering the main activities, contributions and responsibilities of universities, our next stage was to design the disclosure index, which is focused on the search for information about these issues:

- Financial information

- Corporate governance

- Social responsibility

- Research

- Teaching

- Strategic information

- Timeliness of information provided

- Contact information

- Interactions with other users

- Navigability and web structure

The sections devoted to the disclosure of financial information are especially relevant, because they will constitute the basis for the second part of our empirical analysis, that is, the analysis of several factors which may influence a greater financial disclosure. In order to select the financial items, we considered different studies from universities around the world (USA, Canada, England, Wales, Northern Ireland and New Zealand). For instance, Engstrom (1988) proposes certain items, such as: descriptive report, student numbers, operating statement, budget information, balance sheet and investments, among others. In the same line, Broadhurst (1993) also considers items of financial features: descriptive report, accounting policies, student numbers, studentfaculty ratio, operating statement, budget information, statement of cash flows and balance sheet, among others. We also looked at Banks and Nelson (1994), for Ontario universities, Dixon et al. (1991), for New Zealand universities, Banks et al. (1997), for 
universities from England, Wales and Northern Ireland, and Nelson et al. (2003), for Canadian universities.

After defining the items in the index, the following stage was their quantification. When applying this methodology to establish the levels of disclosed information for each item, one can choose a binary variable, which takes a value of either 1 or 0 , depending on whether the data is reported or not (Cooke, 1989), or alternatively one can attempt to estimate a score ranging from 1 to 0 . Although the latter solution may be considered conceptually superior, it can lead to a completely subjective evaluation (Giner, 1995).

In this study, according to the most widely used methodology in online disclosure (e.g. Bonsón and Escobar, 2006, in their study about online transparency in the banking sector), we have opted for the binary variables, which have been widely used in previous studies for universities from different countries (Engstrom, 1988; Banks et al., 1997).

Nevertheless, we assigned a probable score of 2 for some items, because they represent information of a broad content which could be released only partially. These items are:

- Complete annual accounts

- Overall university budget

In these items, partial disclosure is also possible (for instance, disclosing only some reports of the annual accounts, or general aspects of the university budget). In the event of disclosing partial information, we assigned a score of 1 , whereas we opted for a score of 2 when the information is revealed completely.

Last of all, another important issue is the possible weighting of the items, as performed in some studies (Pirchegger and Wagenhofer, 1999; Gandía, 2001). In our research, we chose an unweighted index, given that, according to Giner (1997), there is some arbitrariness inherent to the use of any weighted index. Moreover, studies which use both weighted and unweighted indices draw similar conclusions from both types of indices (Choi, 1973; Chow and Wong-Boren, 1987).

As a result, we have chosen the aggregation of the scores obtained for each item in an unweighted index (as in Cooke, 1989; Raffournier, 1995; Giner, 1997).

After defining the items of information to be included in the disclosure index and studying their quantification and weighting, we performed a thorough analysis of the contents on Spanish university websites. 


\section{Analysis of factors: variables and technique}

After specifying the items considered in the content analysis, we analysed the factors which may have an impact on a greater amount of disclosure on financial issues.

\section{Dependent variable}

We tested a dependence model in which the dependent variable refers to a financial disclosure index, obtained from the financial information revealed by Spanish universities on their websites. Taking into consideration previous studies and placing special emphasis on the disclosure of financial information in universities, we selected the information items to be considered in the disclosure index. Table 1 shows these financial information items.

\section{Independent variables}

Table 2 shows the explanatory variables proposed to test the research hypotheses. The data needed to create these variables were obtained from each university's website.

\section{Analysis technique}

Based on the variables selected to test the hypotheses proposed, we defined model (1), in which the extent of financial information disclosed by universities on their websites is a function of institution size, leverage, university profitability, public versus private university and governance, and other control variables.

Disclosed Information Financial Online $=f$ (Size, leverage, university profitability, public versus private university, governance, age, type of university, internationality, research orientation, complexity, growth-reduction of students)

\begin{tabular}{|l|}
\hline 1. Overall annual accounts (Balance, Income Statement, Report, Budget liquidation and Cash Surplus) \\
\hline 2. Annual accounts: partial information \\
\hline 3. Overall university budget (Includes revenues budget and expenses budget) \\
\hline 4. University budget: general indications \\
\hline 5. Information about previous years (3 or 5 years) \\
\hline 6. Evolution graphic \\
\hline 7. External auditing report \\
\hline 8. 'Account Court' report \\
\hline 9. Existence of internal auditing (Link to this service, with updated information) \\
\hline 10. Financial resources stemming from teaching activities (fees, etc.) \\
\hline 11. Financial resources stemming from research activities \\
\hline 12. Information from different faculties / departments \\
\hline 13. Information on student numbers and unit cost per student \\
\hline
\end{tabular}

Table 1. Financial information items 
The model (1) can be empirically estimated using the equation (2):

$$
\begin{gathered}
\text { DIF }_{i}=\beta_{0}+\beta_{1} \text { Size }_{i}+\beta_{2} \text { Lev }_{i}+\beta_{3} \text { UniProfit }_{i}+\beta_{4} \text { UniPriv }_{i}+\beta_{5} \text { Governance }_{i}+\beta_{6} \\
\text { Antiquity }_{i}+\beta_{7} \text { TypeUni }_{i+} \\
\beta_{8} \text { Internationality }_{i}+\beta_{9} \text { Research }_{i}+\beta_{10} \text { Complexity }_{i}+ \\
\beta_{11} \text { VariatStud }_{i}+\varepsilon
\end{gathered}
$$

In which:

- $\boldsymbol{D I} \boldsymbol{F}_{\boldsymbol{i}}$ is the financial disclosure index obtained after analysing university i's website; Size $_{\boldsymbol{i}}$ is university i's number of students as a variable related to corporate size;

- $\boldsymbol{L e v}_{\boldsymbol{i}}$ is university i's leverage, established as the ratio between debt volume and total assets;

- UniProfit ${ }_{i}$ is the university profitability for university i, own revenue per capita defined as the ratio total revenue / number of students;

- UniPriv $\boldsymbol{v}_{\boldsymbol{i}}$ is a dummy variable which takes the value 1 if the university is private, and 0 , otherwise,

- Governance $_{i}$ is the number of members on the governing board of the university; $\boldsymbol{A g} \boldsymbol{e}$ is the number of years since the university's founding;

- TypeUni $i_{i}$ is the number of technical degrees offered by the university;

- Internationality $i$ is the number of foreign students in the university;

- $\boldsymbol{R e s e a r c h}_{i}$ is the ratio between $\mathrm{PhD}$ theses presented and the number of students in each university;

- Complexity $i$ is the number of faculties in each university;

- VariatStud $_{i}$ is the growth-reduction in the number of students from 2006 to 2007.

Model (2) was checked empirically through a linear regression, estimated by OLS. As mentioned above, the dependent variable was obtained from the analysis of items in the disclosure index of the websites. 


\begin{tabular}{|l|l|c|}
\hline Variable & Definition & Hypothesis/Expected sign \\
\hline SIZE & $\begin{array}{l}\text { University size, measured through the number of } \\
\text { students }\end{array}$ & H1 \\
\hline LEVERAGE & Debt ratio, measured by total debt / total assets ratio & H2 \\
\hline UNIPROFIT & $\begin{array}{l}\text { Own revenue per capita, represented by total revenue } \\
\text { /total students ratio }\end{array}$ & H3 \\
\hline UNIPRIV & $\begin{array}{l}\text { Dummy variable which takes the value 1 if the } \\
\text { university is private, and 0, otherwise }\end{array}$ & H4 \\
\hline GOVERNANCE & $\begin{array}{l}\text { Number of members of the university's management } \\
\text { bodies (generally the president's team) }\end{array}$ & H5 \\
\hline AGE & Number of years since the foundation year & H6 \\
\hline INTERNATIONALITY & Number of foreign students & + \\
\hline TYPE OF UNIVERSITY & $\begin{array}{l}\text { Number of technical degrees offered by the } \\
\text { university analysed }\end{array}$ & + \\
\hline RESEARCH ORIENTATION & Ratio of PhD Dissertations over number of students & + \\
\hline COMPLEXITY & Number of faculties in each university & $\begin{array}{l}\text { Variation in the number of students from 2006 to } \\
2007\end{array}$ \\
\hline VARIATION IN STUDENTS & & \\
\hline
\end{tabular}

Table 2. Variables

\section{RESULTS}

\section{Content analysis of university websites}

As stated above, we first performed a content analysis of Spanish universities' websites. The results are displayed and commented on according to the different groups of items analysed.

\section{Financial information}

Table 3 summarises the findings for the financial information disclosed by Spanish universities.

First, it is worth emphasizing that Spanish universities disclose a low volume of financial and economic information. They hardly disclose information about annual accounts; $14.3 \%$ report the whole set of annual accounts (Balance Sheet, Income Statement, Report, Budget liquidation, Cash surplus) and $18.6 \%$ reveal some aspects of the accounts. Moreover, public universities tend to disclose a significantly greater volume compared to private universities (Chi-squared $=5.347 * * *$ for overall information; Chisquared $=7.317^{* * *}$ for partial information). On the other hand, most universities report 
information on financial budgets (Revenues Budget and Expenses Budget), usually specifying the origins of funds (teaching and research) and the distribution among departments and faculties.

Other relevant items which can facilitate financial and economic analysis are disclosed in a minor way: Auditing Report (7.1), evolution graphs (20), information about previous years (27.1), and the Account Court's report (2.9). Overall, the mean of items reveals that 4.79 out of the 13 potential items are disclosed by each university, on average.

\begin{tabular}{|l|c|}
\hline Financial Information & \% \\
\hline Overall annual accounts & 14.3 \\
\hline Annual accounts: partial information & 18.6 \\
\hline Overall university budget & 54.3 \\
\hline University budget: general indications & 18.6 \\
\hline Information about previous years (3 or 5 years) & 27.1 \\
\hline Evolution graphic & 20 \\
\hline External auditing report & 7.1 \\
\hline 'Account Court' report & 2.9 \\
\hline Existence of internal auditing & 27.1 \\
\hline Financial resources stemming from teaching activities (fees, etc.) & 50 \\
\hline Financial resources stemming from research activities & 54.3 \\
\hline Information from different faculties / departments & 60 \\
\hline Information on the number of students and unitary cost per student & 45.7 \\
\hline Mean of items & 4.79 \\
\hline
\end{tabular}

Table 3: Financial information disclosed by Spanish universities

\section{Corporate Governance}

The items related to corporate governance (Table 4) are more widely disclosed by Spanish universities, especially those concerning the description of individual and collective governing bodies (67 \% and $70 \%$, respectively). Graphics and vicechancellors' CVs are not often revealed. News and agenda are disclosed to some extent (59\%). On average, Spanish universities reveal 6.14 out of the 13 potential items analysed (mean figure in Table 4).

\section{Social Responsibility (SR)}

Similarly to the disclosure of corporate financial information, universities seem to be reluctant to reveal aspects of social responsibility (Table 5). Only $2.9 \%$ disclose a global report on SR and $17 \%$ display a partial report (a summary of social responsibility 
activities without elaboration), whereas $27 \%$ reveal a report on environmental and social impact. Twenty-nine per cent disclose some aspects of sustainability. On the other hand, a high percentage of universities have implemented a system for quality evaluation (76\%).

\begin{tabular}{|l|c|}
\hline Governance information & \% \\
\hline Vice-Chancellor's Report & 67 \\
\hline Description of the individual governing positions & 56 \\
\hline Web page for each Pro-Vice Chancellorship & 23 \\
\hline Pro-Vice-Chancellors' Curriculum Vitae & 70 \\
\hline Description of the collegiate organs of government & 51 \\
\hline Web page for the main collegiate organs & 56 \\
\hline Composition of commissions and committees & 59 \\
\hline News about meetings / Agenda & 41 \\
\hline Availability of the information provided in the Univ. Senate, Governing \\
Board & 53 \\
\hline Press news & 14 \\
\hline Organisation chart & 70 \\
\hline Link to University Ombudsman & 37 \\
\hline Existence of an ethics code / disciplinary code & 6.14 \\
\hline Mean & \\
\hline
\end{tabular}

Table 4: Governance information disclosed by Spanish universities

\begin{tabular}{|l|c|}
\hline Social Responsibility Information & \% \\
\hline Complete Social Responsibility Report (2 points) & 2.9 \\
\hline Partial Social Responsibility Report (1 point) & 17 \\
\hline Report on environmental or social impact & 27 \\
\hline Information set out according to GRI guidelines & 1 \\
\hline External verification & 3 \\
\hline Disclosure of the policy on sustainable development & 29 \\
\hline Strategic planning of sustainability & 20 \\
\hline Planning of specific activities on sustainability & 7 \\
\hline Implementation of a system of quality evaluation & 76 \\
\hline Mean & 1.86 \\
\hline
\end{tabular}

Table 5: Disclosure of SR in Spanish universities

\section{Research}

Since universities are institutions with a specific purpose for research, most of them are expected to use the Internet in order to reveal their aims and achievements. As expected, the scores for research reach higher values compared to SR or financial 
information (on average, 5.69 out of 9 items, according to the mean). Although Research Reports are scarcely disclosed ( $23 \%$ in a summarised report), most universities reveal information on R\&D projects (80 \%), research groups (91\%) and congresses and scientific conferences $(89 \%)$. In addition, many of them describe public subventions for research $(79 \%)$ (Table 6).

Public universities disclose research activities more intensely in comparison to private universities, with significant differences between them (for example, Chi-squared $=6.063 * * *$ in the disclosure of a complete Research Report).

\begin{tabular}{|l|c|}
\hline Research information & \% \\
\hline Complete Research Report (2 points) & 28.6 \\
\hline Partial Research Report (1 point) & 23 \\
\hline Information on R\&D projects & 80 \\
\hline Information on research groups & 91 \\
\hline Information on congresses and scientific activities & 89 \\
\hline Collaboration agreements with Basic Research centres & 67 \\
\hline Patents registered, brands and licences of the university & 34 \\
\hline Information on Ph.D. theses & 46 \\
\hline Existence of policies of internal subsidies for research & 79 \\
\hline Mean & 5.69 \\
\hline
\end{tabular}

Table 6: Disclosure of Research in Spanish Universities

\section{Teaching}

As well as disclosure for research, the revelation of information about teaching activities - the other main purpose of universities - is expected to attain high scores. As Table 7 reflects, these items are widely disclosed by Spanish universities. Almost all of them reveal information on grants and fellowships. Seventy-three per cent have a direct link to departments and faculties and $59 \%$ exhaustively describe the enrolment process. Considered overall, the scores obtained for teaching disclosures also reaches high values (5.27 out of 9), compared to other groups of items. There are no important and significant differences between public and private universities in the disclosure of certain issues, such as grants, student-teacher ratios or number of students (Table 7).

\section{Strategic information}

The disclosure of strategic plans and objectives is made by just half of Spanish universities. Fifty-four per cent reveal general strategic objectives, while $46 \%$ disclose 
specific aspects concerning strategy issues. On average, they disclose 1.13 out of 4 potential items (Table 8).

\begin{tabular}{|l|c|}
\hline Teaching activities & \% \\
\hline Direct access and link to faculties' and departments' websites & 73 \\
\hline Academic guides & 59 \\
\hline Description of the enrolment process & 59 \\
\hline Information on grants & 99 \\
\hline Information on mobility & 89 \\
\hline Online enrolment process & 63 \\
\hline Pre-enrolment process online & 23 \\
\hline Teacher - Student ratios & 11 \\
\hline Number of students & 54 \\
\hline Mean & 5.27 \\
\hline
\end{tabular}

Table 7: Disclosure of teaching activities in Spanish universities

\begin{tabular}{|l|c|}
\hline Strategic information & \% \\
\hline Strategic objectives of the university & 54 \\
\hline Strategic alliances and agreements & 7 \\
\hline Strategic position of the university in its sector (ranking) & 46 \\
\hline Drawing-up of specific objectives / Annual planning & 1.13 \\
\hline Mean & 7 \\
\hline
\end{tabular}

Table 8: Strategic information disclosed by Spanish universities

\section{Timeliness}

Current news and relevant events are revealed by almost the whole set of Spanish universities. Many universities have internal bulletins, disclosed on their websites. The date of last update is only disclosed by $21 \%$; however, given that university websites are especially dynamic - at least, in research and teaching disclosures - this item may not be representative (Table 9).

\begin{tabular}{|l|c|}
\hline Timeliness of information & $\mathbf{\%}$ \\
\hline Current news & 97 \\
\hline Academic calendar - Important events & 94 \\
\hline Date of last update (Frequent update $<3$ months) & 21 \\
\hline Indication of number of visitors & 6 \\
\hline Mean & 2.17 \\
\hline
\end{tabular}

Table 9: Timeliness of information disclosed by Spanish universities 


\section{Contact information}

Most Spanish universities show contact information, by post, email or phone. In addition, many of them present their information in other languages (usually English) and offer a personnel directory to search for specific individuals (59\%) (Table 10).

\begin{tabular}{|l|c|}
\hline Contact information & \% \\
\hline Contact e-mail & 96 \\
\hline Postal address for contact & 97 \\
\hline Phone contact & 96 \\
\hline English version & 76 \\
\hline FAQ & 13 \\
\hline Contact online & 34 \\
\hline Suggestion box & 43 \\
\hline Staff directory & 59 \\
\hline Mean & 5.13 \\
\hline
\end{tabular}

Table 10: Contact information available on universities' websites

\section{Interactivity with users}

University websites permit users to have a wide range of interactive possibilities. Information on libraries, cultural activities and other university services (e.g. languages, sports) are extensively disclosed. In addition, teachers and auxiliary personnel can receive information through the Internet. However, at the current stage, other possibilities of administration management online are limited (Table 11).

\begin{tabular}{|l|c|}
\hline Interactivity & \% \\
\hline Access and link to information on libraries (catalogue, bibliographic databases, etc.) & 97 \\
\hline Access and link to information on social and cultural activities and other events & 97 \\
\hline Information on other university services: foreign languages, sports, radio, etc. & 99 \\
\hline Information on staff: positions, promotion, etc. & 79 \\
\hline Information on and for auxiliary personnel & 67 \\
\hline Possibilities of administrative activities online & 14 \\
\hline Possibilities of document presentation online & 14 \\
\hline Mean & 4.67 \\
\hline
\end{tabular}

Table 11: Interactivity with users in Spanish universities' websites

\section{Navigability and website structure}

All the websites are designed so that information for students and information on administration, current news and research activities can be reached immediately. These 
structures are supported by internal search engines, webmaps and contents display. The existence of restricted areas is also widely used by universities (86\%) (Table 12).

\begin{tabular}{|l|c|}
\hline Navigability & \% \\
\hline Help button (demos, etc.) & 21 \\
\hline Web map / Table of Contents & 89 \\
\hline Pull down menu & 76 \\
\hline Click over menu & 74 \\
\hline Internal search engine & 57 \\
\hline Back button / Next button for sequential navigation & 37 \\
\hline Newsletters & 7 \\
\hline Contents menu always visible & 56 \\
\hline Mean Items Navigability & 4.19 \\
\hline No. of clicks needed to get to Students - Enrolment (2 clicks) & 100 \\
\hline No. of clicks needed to get to Research & 99 \\
\hline No. of clicks needed to get to latest news items or press & 100 \\
\hline No. of clicks needed to get to Administration & 97 \\
\hline Print option available in a suitable format & 27 \\
\hline Existence of a restricted area (e.g. for teaching staff) & 86 \\
\hline Contact with the web-master & 23 \\
\hline Mean Items Structure & 5.31 \\
\hline
\end{tabular}

Table 12: Navigability and website structure in Spanish universities

Table 13 (Panel A) summarises the main findings of the groups of items considered. As for the webs' contents, websites usually focus on research and teaching activities, given that universities reveal 63.23 -research- and 58.56 -teaching-per cent of the items analysed, on average. Consequently, universities use their websites in order to disclose their main contributions to society, to a greater extent than other relevant issues, such as governance (47.23\%), financial information (36.84\%), strategic information $(28.25 \%)$ and social responsibility $(20.67 \%)$.

Therefore, websites are a mechanism for interacting with the main interest groups: students, researchers and teachers. They usually omit information which can be considered of interest and use for other groups, such as tax-payers, funds providers, pressure groups, etc.

With regard to structure and navigability, universities' websites attain relatively high scores, showing an appropriate structure for access, with diverse possibilities of interactions with users -although with limitations in administration management onlineand contact information. 


\begin{tabular}{|l|c|c|}
\hline Groups of items & Items disclosed & \% \\
\hline Financial information & $4.79 / 13$ & 0.3684 \\
\hline Corporate governance & $6.14 / 13$ & 0.4723 \\
\hline Social responsibility & $1.86 / 9$ & 0.2067 \\
\hline Research & $5.69 / 9$ & 0.6323 \\
\hline Teaching & $5.27 / 9$ & 0.5856 \\
\hline Strategic information & $1.13 / 4$ & 0.2825 \\
\hline Timeliness & $2.17 / 4$ & 0.5425 \\
\hline Contact information & $5.13 / 8$ & 0.6412 \\
\hline Interactions with users & $4.67 / 7$ & 0.6671 \\
\hline Navigability & $4.19 / 8$ & 0.5237 \\
\hline Structure & $5.31 / 7$ & 0.7585 \\
\hline
\end{tabular}

Table 13: Panel A. Disclosure ranking summary

Subsequently, we performed some tests of differences between means on these indices, according to certain variables whose influence will be analysed in the following section. With that purpose, we created two balanced subsamples from the whole sample, by dividing up through the median, in the following variables: profitability, size, age, internationality, growth of students, leverage, technical degrees and research intensity, in order to check whether there are significant differences in the main disclosure indices, according to these variables. We use two non-parametric tests: Mann-Whitney's U and Kolmogorov-Smirnov's Z. Table 13 (Panel B) summarises the findings, displaying the sign of the difference and the results of Mann-Whitney's U (and reporting if there is some divergence with the Kolmogorov-Smirnov's Z).

According to the tests, the following differences stand out:

- Larger and older universities reveal more information on financial issues, as well as those more technically focused and with a lower leverage; there are no significant differences in the disclosure of financial information, according to the remaining variables: profitability, research intensity, internationality and growth of students.

- Information on corporate governance is more disclosed by less profitable, larger, more traditional, more internationally-focused universities, as well as those with more technical degrees and a minor growth in student numbers.

- There seem to be significant differences in the disclosure of information on social responsibility only between large / small universities. 
- Those more traditional and larger universities reveal a higher amount of information on research issues, without differences detected amongst other variables.

- In addition, size and age lead to a larger disclosure of teaching activities, with a negative impact of profitability.

- Finally, strategic information is mainly disclosed by those universities that are larger, more traditional and more internationally-focused.

- Therefore, apparently, only size and age are sufficiently influential to determine a higher extent of revelation in the main disclosure indices, considering these variables individually in the tests of differences between means.

\begin{tabular}{|c|c|c|c|c|c|c|}
\hline Mann-Whitney's U & \multicolumn{2}{|c|}{ Financial information } & \multicolumn{2}{|c|}{ Corporate Governance } & \multicolumn{2}{|c|}{ Social responsibility } \\
\hline Profitability & - & $434(0.653)$ & - & $313.5(0.028)^{* *}$ & + & $393.5(0.283)$ \\
\hline Size & + & $309(0.012) * *$ & + & $184.5(0.000)^{* * *}$ & + & $327.5(0.020)^{* *}$ \\
\hline Age & + & $309(0.001) * * *$ & + & $318(0.002)^{* *}$ & + & $457(0.173)$ \\
\hline Internationality & + & $366.5(0.153)$ & + & $323(0.039) * *$ & + & $370.5(0.156)$ \\
\hline Growth of students & - & $511.5(0.314)$ & - & $456(0.093)^{*} \dagger$ & + & $533.5(0.442)$ \\
\hline Leverage & - & $195(0.053)^{*} \dagger$ & - & $270(0.707)$ & - & $260.5(0.554)$ \\
\hline Technical degrees & + & $355.5(0.068)^{*}$ & + & $334.5(0.034) * * \dagger$ & + & $434.5(0.458)$ \\
\hline Research Intensity & + & $301(0.371)$ & + & $318(0.554)$ & + & $303(0.375)$ \\
\hline Mann-Whitney's U & & Research & & Teaching & \multicolumn{2}{|c|}{ Strategic information } \\
\hline Profitability & + & $452.5(0.855)$ & - & $347.5(0.084)^{*} \dagger$ & + & $456(0.892)$ \\
\hline Size & + & $281.5(0.004)^{* * * *}$ & + & $210.5(0.000)^{* * *}$ & + & $278(0.002)^{* * *}$ \\
\hline Age & + & $332(0.004)$ & + & $338(0.005)^{* *}$ & + & $369.5(0.012) * *$ \\
\hline Internationality & + & $387(0.256)$ & + & $381.5(0.220)$ & + & $300.5(0.013)$ \\
\hline Growth of students & - & $464(0.113)$ & - & $516(0.336)$ & - & $563(0.686)$ \\
\hline Leverage & - & $255(0.489)$ & + & $285.5(0.958)$ & + & $228(0.190)$ \\
\hline Technical degrees & + & $457.5(0.689)$ & + & $439(0.506)$ & + & $395.5(0.187)$ \\
\hline Research Intensity & + & $319.5(0.570)$ & + & $320.5(0.580)$ & + & $299(0.332)$ \\
\hline
\end{tabular}

Table 13. Panel B. Tests of differences of means between groups 


\section{Empirical analysis: factors behind the disclosure of financial information}

After performing a content analysis of Spanish universities' websites, we checked the influence of certain factors on the disclosure of financial information. Previously, the descriptive statistics and correlations amongst the variables studied are reflected in Table 14 (Panel A). On average, Spanish universities have a leverage of $67 \%$, a profitability of $€ 9293$ per student, 10 Pro-Vice-Chancellors, 30,779 students, 17 faculties, 15 technical degrees in each university and about 816 foreign students, although there are some variables -for instance, size, profitability or internationality- with a high variability (standard deviation).

\begin{tabular}{|l|r|r|r|r|r|}
\hline & Mean & Median & Maximum & Minimum & Stand. Dev. \\
\hline DIF & 4.79 & 6.00 & 11 & 0 & 2.70 \\
\hline Lev & 0.67 & 0.81 & 0.95 & 0.10 & 0.25 \\
\hline UniProfit & 9293.23 & 7853.93 & 49242.81 & 1078.67 & 7828.39 \\
\hline Governance & 9.88 & 10 & 16 & 6 & 10 \\
\hline UniPriv & 0.03 & 0 & 1 & 0 & 0.74 \\
\hline Size & 30779 & 19360 & 180000 & 6085 & 32525.5 \\
\hline Age & 158.58 & 30 & 790 & 9 & 240.1 \\
\hline Research & 0.006 & 0.005 & 0.02 & 0.00 & 0.005 \\
\hline Complexity & 17.27 & 16 & 38 & 3 & 8.73 \\
\hline Internationality & 816 & 310 & 7432 & 9 & 1376 \\
\hline VariatStud & 1855 & 1459 & 35423 & -37213 & 9584 \\
\hline TypeUni & 15 & 12 & 49 & 3 & 10.23 \\
\hline
\end{tabular}

Table 14. Panel A. Descriptive statistics

Concerning the correlations amongst the variables studied (Table 14, Panel B), the highest correlations with the dependent variable are shown in the variables UniPri (0.591), Governance (0.551) and Leverage (-0.523), which stresses that the disclosure of financial information is mainly undertaken by public universities with a larger number of Pro-Vice-Chancellors and with a lower level of debt.

The findings of the empirical analysis are shown in Table 15. The results obtained show that leverage and complexity have significant effects, at 99 and $95 \%$, respectively, both with a negative sign. On the contrary, governance, size, age, research orientation, internationality and type of university display positive signs, but their effects are statistically non-significant at $90 \%$. Finally, profitability, private university and variation in student number exhibit negative signs; however, the impact on disclosure is statistically non-significant and therefore these factors do not influence the revelation of financial disclosure from a statistical perspective. 


\begin{tabular}{|c|c|c|c|c|c|c|}
\hline & DIF & Lev & UniProfit & Governance & UniPri & Size \\
\hline DIF & 1 & $-0.523(* *)$ & -0.025 & $0.551(* *)$ & $-0.591(* *)$ & $0.458(* *)$ \\
\hline Lev & $-0.523(* *)$ & 1 & 0.081 & 0.023 & $-0.295(*)$ & -0.190 \\
\hline UniProfit & -0.025 & 0.081 & 1 & 0.029 & -0.074 & -0.178 \\
\hline Governance & $0.551(* *)$ & 0.023 & 0.029 & 1 & $-0.778(* *)$ & $0.583(* *)$ \\
\hline UniPriv & $-0.591(* *)$ & $-0.295(*)$ & -0.074 & $-0.778(* *)$ & 1 & $-0.393(* *)$ \\
\hline Size & $0.458(* *)$ & -0.190 & -0.178 & $0.583(* *)$ & $-0.393(* *)$ & 1 \\
\hline Age & $0.263(*)$ & -0.122 & -0.101 & 0.246 & $-0.282(*)$ & $0.384(* *)$ \\
\hline Research & 0.087 & 0.083 & $0.564(* *)$ & 0.143 & -0.214 & -0.041 \\
\hline Complexity & $0.323(* *)$ & -0.032 & 0.240 & $0.499(* *)$ & $-0.579(* *)$ & $0.352(* *)$ \\
\hline Internationality & $0.347(* *)$ & -0.236 & -0.102 & $0.390(* *)$ & -0.194 & $0.880(* *)$ \\
\hline VariatStud & 0.153 & -0.142 & $-0.717(* *)$ & 0.262 & -0.075 & $0.630(* *)$ \\
\hline \multirow[t]{2}{*}{ TypeUni } & $0.278(*)$ & -0.062 & $0.423(* *)$ & 0.239 & $-0.374(* *)$ & 0.084 \\
\hline & Age & Research & Complexity & International. & VariatStud & TypeUni \\
\hline DIF & $0.263(*)$ & 0.087 & $0.323(* *)$ & $0.347(* *)$ & 0.153 & $0.278(*)$ \\
\hline Lev & -0.122 & 0.083 & -0.032 & -0.236 & -0.142 & -0.062 \\
\hline UniProfit & -0.101 & $0.564(* *)$ & 0.240 & -0.102 & $-0.717(* *)$ & $0.423(* *)$ \\
\hline Governance & 0.246 & 0.143 & $0.499(* *)$ & $0.390(* *)$ & 0.262 & 0.239 \\
\hline UniPriv & $-0.282(*)$ & -0.214 & $-0.579(* *)$ & -0.194 & -0.075 & $-0.374(* *)$ \\
\hline Size & $0.384(* *)$ & -0.041 & $0.352(* *)$ & $0.880(* *)$ & $0.630(* *)$ & 0.084 \\
\hline Age & 1 & 0.056 & $0.438(* *)$ & 0.218 & 0.107 & 0.041 \\
\hline Research & 0.056 & 1 & $0.365(* *)$ & -0.001 & $-0.504(* *)$ & 0.268 \\
\hline Complexity & $0.438(* *)$ & $0.365(* *)$ & 1 & 0.146 & -0.159 & $0.484(* *)$ \\
\hline Internationality & 0.218 & -0.001 & 0.146 & 1 & $0.561(* *)$ & -0.002 \\
\hline VariatStud & 0.107 & $-0.504(* *)$ & -0.159 & $0.561(* *)$ & 1 & $-0.337(*)$ \\
\hline TypeUni & 0.041 & 0.268 & $0.484(* *)$ & -0.002 & $-0.337(*)$ & 1 \\
\hline
\end{tabular}

Table 14. Panel B. Correlations matrix

Therefore, the findings show a non-significant influence of economic profitability, university size, the status of private university and governance size. As for the other variables included, there are no significant effects derived from internationality, variation 
in student numbers, age, research orientation or type of university. Consequently, the low extent of financial disclosure in many items is common to universities with different levels of profitability, private versus public status, size, number of pro-vice-chancellors, growth-reduction in student numbers, age, research orientation and type of university. Size and profitability -two important drivers of corporate disclosure for companies- do not imply a positive trend to reveal issues related to finance and origins of funds. Apparently, the disclosure of information by universities does not seem to follow the logical implications of disclosure by private companies. Also, these findings show the low degree of disclosure culture developed by Spanish universities, given that they do not seem to respond to some factors whose influence has been confirmed in other countries (e.g. Banks et al., 1997) and other public institutions. These findings, combined with those described above, reaffirm the low extent of public scrutiny for Spanish universities, perhaps due to the fact that universities are scrutinized by the Account Court and the general public trusts this Court's reports.

\begin{tabular}{|l|c|}
\hline Variable & Standarised coefficients \\
\hline Leverage & -0.452 \\
& $(-3.087)^{* * *}$ \\
\hline Profitability & -0.346 \\
& $(-1.365)$ \\
\hline Governance & 0.137 \\
& $(0.809)$ \\
\hline Private university & -0.009 \\
& $(-0.063)$ \\
\hline Size & 0.378 \\
& $(0.996)$ \\
\hline Age & 0.046 \\
& $(0.295)$ \\
\hline Research Orientation & 0.061 \\
& $(0.360)$ \\
\hline Complexity & -0.342 \\
& $\left(-2.026^{* *}\right)$ \\
\hline Internationality & 0.072 \\
& $(0.226)$ \\
\hline Variation of students & -0.473 \\
& $(-1.455)$ \\
\hline Type of University & 0.223 \\
& $(1.371)$ \\
\hline F & $2.385^{* *}$ \\
\hline $\mathrm{R}^{2}$ & 0.428 \\
\hline
\end{tabular}

Table 15: Factors behind financial disclosure. Dependent variable: index of financial disclosure 
On the other hand, financial leverage has an impact on the disclosure of financial information, but in a negative relationship. Therefore, universities do not follow the logical implications of debt for quoted companies, according to the agency theory, which states a direct relationship between debt and disclosure. For universities, given that their economic and financial development and activities are overseen by a public body -the "Account Court"-, the implications of debt are contrary to those expected for private companies. Since Spanish universities are mainly supported by the public administration, they do not usually have to face difficulties in obtaining new funds from public and private organizations (such as banks). Thus, the negative association debt-disclosure may signal that universities with a greater degree of financial independence are willing to reveal this independence, whereas universities with larger volumes of debt are reluctant to disclose their own situation. Therefore, it seems that behind the disclosure behaviour there is the desire to release a good image.

Furthermore, complexity exhibits an inverse association with the revelation of financial information. This relationship may be due to the fact that the disclosure of information may be favoured or hindered by the size of the university (as Darnall et al., 2000, have suggested for other public institutions). While small universities have the advantage that the implementation of a disclosure system is simpler, as regards organization, management and revelation, larger universities -owing to the higher amount of competences they have to deal with- would need a higher degree of control which can mean that the disclosure of financial information may be lower. In addition, the most complex universities will delegate some of the functions of the main website to faculty websites, which can lead to a lower amount of information on the main website.

\section{CONCLUSIONS}

The use of the Internet by public organizations and institutions is a fast-growing trend in many contexts. Together with the advantages of costs savings, the Internet provides users with timely and updated information and allows them to interact with public institutions and companies.

Universities, as public institutions in some cases and as private companies in other cases, can improve their relationships with users - e.g. students, teachers, auxiliary personnel and so on - through the disclosure of their services on the Internet, revealing information about their finances, research and teaching activities, and through the possibilities of interacting with users. As institutions which create knowledge and train 
the future generations of a country, universities have a special importance for societies and their influence reaches a wide range of users.

In this study we first aimed to describe the main contents of Spanish universities, focusing on financial information, governance, corporate social responsibility, teaching activities and research, amongst other aspects. Our findings emphasize that website contents usually have to do with research and teaching activities to a high degree, which can be regarded as their main contribution to society. In second place, they reveal their own mechanisms of governance. Other issues such as social responsility or strategic information are less widely disclosed. And finally, financial information is scarcely disclosed by Spanish universities, both in private and public institutions. Consequently, there is a lack of transparency in the disclosure of financial information on the part of Spanish universities. Annual accounts are hardly revealed, while financial budgets usually show a greater volume of disclosure. Therefore, these findings emphasize the low development of a disclosure culture for financial issues by Spanish universities.

In a subsequent research stage, we analysed certain factors that may influence the disclosure of financial information on the part of Spanish universities. The low degree of disclosure is common to universities which are different in size, private versus public status, economic profitability, internationality, research orientation, type of university and number of governance members. No influence of size or profitability on the disclosure of financial information was detected. On the other hand, we obtained an inverse association between complexity -number of faculties- and disclosure, which may be a result of the diversification of competences in large universities and the delegation of disclosure to faculties' own websites. Moreover, we also find an inverse relationship between leverage and disclosure, contrary to that expected for firms. These findings suggest that lowleveraged universities may tend to reveal more financial information in order to show their higher degree of financial independence. On the contrary, universities with large levels of debt are reluctant to disclose their internal situations, by revealing less financial information and, more specifically, information about debt (contained mainly in the annual accounts).

Consequently, our findings stress the low degree of revelation of financial information by universities. Given that they are significant receptors of public funds, we believe that it is not enough to know that their managements are monitored by public agencies; universities must reveal information about their financial status and situation to the general public, who is paying for their functioning directly or indirectly. In order to 
enhance their transparency in the use of public funds and resource allocations, universities should increase the disclosure of financial information, even on a regulatory basis.

In line with many of the studies using the methodology of disclosure indices, our work faces some limitations. Firstly, the use of an unweighted index may be regarded as a simplification, although this kind of index has been widely used in previous works in this vein (e.g. Giner, 1997). Secondly, although we study the whole set of Spanish universities -both public and private-, the number of observations is reduced; therefore, our findings could be made more consistent by broadening the scope of study to universities from other countries. Thirdly, we analyse only the main website of each university, which is usually the first to be accessed from the perspective of the general public. Finally, there are other factors that have an indubitable influence on the disclosure of information by universities and that have been omitted from this study; for instance, the importance of social activities undertaken by universities, or the degree of internationalization. These drivers should be analysed more in depth in future studies, at the same time that an international perspective would be necessary to complement the findings obtained here.

\section{REFERENCES}

ÁLVAREZ, A. (2007): "Corporate firm characteristics and human resource disclosures in Spain", paper presented at the $30^{\text {th }}$ Annual European Accounting Association Congress, Lisbon, 25-27 April.

AMERICAN COUNCIL ON EDUCATION (1995): Educating Americans for a World in Flux: Ten Ground Rules for Internationalizing Higher Education. Washington, D.C.: American Council on Education.

ANGLUIN, D.; SCAPENS, R.W. (2000): “Transparency, Accounting Knowledge and Perceived Fairness in UK Universities' Resource Allocation: Results from a Survey of Accounting and Finance", British Accounting Review, 32, 1-42.

ANECA (2008): Programa de mención de calidad a los programas de doctorado, V. 02 $(25 / 3 / 2008)$.

BABER, W. (1983): "Towards Understanding the Role of Auditing in the Public Sector", Journal of Accounting and Economics, 5, 213-228.

BADRE, A. (2002): Shaping Web Usability: Interaction Design in Context, Boston: Addison-Wesley. 
BANKS, W.; FISHER, J.; NELSON, M. (1997): "University accountability in England, Wales and Northern Ireland: 1992-1994", Journal of International Accounting, Auditing and Taxation, 6 (2): 211-227.

BANKS, W.; NELSON, M. (1994): "Financial disclosures by Ontario universities: 19881993", Journal of International Accounting, Auditing and Taxation, 3 (2): 287-305.

BOESSO, G.; KUMAR, K. (2007): "Drivers of corporate voluntary disclosure. A framework and empirical evidence from Italy and the United States", Accounting, Auditing and Accountability Journal, 20 (2), 269-296.

BONSÓN, E.; ESCOBAR, T. (2004): "La difusión voluntaria de información financiera en Internet. Un análisis comparativo entre Estados Unidos, Europa del Este y la Unión Europea”, Revista Española de Financiación y Contabilidad, 33 (123), 1063-1101.

BONSÓN, E.; ESCOBAR, T.; FLORES, F. (2006): "Online transparency of the banking sector", Online Information Review, 30 (6), 740-730.

BONSÓN-PONTE, E.; ESCOBAR-RODRÍGUEZ, T.; FLORES-MUÑOZ, F. (2008): "Navigation quality as a key value for the webpage of a financial entity", Online Information Review, 32 (5), 623-634.

BRICALL, J. (2000): Informe Universidad 2000. Publicado por la CRUE (Conferencia de Rectores de las Universidades Españolas.

BROADHURST, W.H. (1993): University Accountability: A Strengthened Framework. The Task Force on University Accountability, Ministry of Education and Training, Province of Ontario: Toronto.

BUENADICHA, M.; CHAMORRO, A.; MIRANDA, F.J.; GONZÁLEZ, O.R. (2001): "A New Web Assessment Index: Spanish Universities Analysis", Internet Research, 11 (3), 226-234.

CAÑIBANO, L. (2008): "Higher Education in 'Business Administration' in Spain: Adapting to the European Area of Higher Education”, Revista Española de Financiación y Contabilidad, 37 (139), 589-597.

CAVE, M.; HANNEY, S.; KOGAN, M. (1997): The Use of Performance Indicator in Higher Education, London: Jessica Kingsley.

CHANDLER, K.; HYATT, M. (2003): Customer-centered design: a new approach to Web usability. Upper Saddle River, NJ: Prentice Hall. 
CHOI, F. (1973): "Financial disclosure and entry to the European capital market", Journal of Accounting Research, 11, 159-175.

CHOW, C.; WONG-BOREN, A. (1987): "Voluntary financial disclosures by Mexican corporations", Accounting Review, 62, 533-541.

CHRISTIAENS, J. (1999): "Financial accounting reform in Flemish municipalities: An empirical investigation", Financial Accountability \& Management, 15 (1), 21-40.

COMISIÓN DE LAS COMUNIDADES EUROPEAS. (2003): El papel de las universidades en la Europa del conocimiento, Comunicación de la Comisión: COM, 5 de febrero de 2003, 58 final.

COOKE, T.E. (1989): "Voluntary Disclosure by Swedish Companies", Journal of International Financial Management and Accounting, 1, 171-195.

COY, D.; DIXON, K.; BUCHANAN, J.; TOWER, G. (1997): "Recipients of Public Sector Annual Reports: Theory and an Empirical Study Compared", The British Accounting Review, 29, 103-127.

COY, D.; FISCHER, M.; GORDON, T. (2001): "Public Accountability: A New Paradigms for College and University Annual Reports", Critical Perspective on Accounting, 12, 1-31.

COY, D.; GOH, G.H. (1995): "Overhead Cost Allocations by Tertiary Education Institutions", Journal of Institutional Research in Australasia, 24 (1), 31-43.

CRAVEN, B.M.; MARTSON, C.L. (1999): "Financial reporting on the Internet by leading UK companies", European Accounting Review, 8 (2), 321-333.

CRUE (2008): La Universidad Española en Cifras 2008, Madrid (Spain): Conferencia de Rectores de las Universidades Españolas, Observatorio Universitario.

DARNALL, N.; RIGLING-GALLAGHER, D.; ANDREWS, R.N.; AMARAL，D. (2000): "Environmental Management systems: Opportunities for Improves Environmental and Business Strategy?", Environmental Quality Management, Spring, 19.

DIXON, K.; COY, D.; TOWER, G. (1991): "External reporting by New Zealand universities 1985-1989. Improving accountability", Financial Accountability and Management, 7, 159-178. 
DUSTIN, E.; RASCA, J.; MCDIARMID, D. (2002): Quality web systems: performance, security and usability, Boston: Adison Wesley.

ENGSTROM, J. (1988): Information Needs of College and University Financial Decision Makers, Research Report, Stamford, CT: Government Accounting Standards Board.

ENGSTROM, J.H.; FOUNTAIN, J.R. (1989): "College and University Financial Reporting: A Survey of Important Financial Decision Makers", Government Accountants' Journal, 38 (2), 39-49.

ETTREDGE, M.; RICHARDSON, V.; SCHOLZ, S. (2001): "The presentation of financial information at corporate Web sites", International Journal of Accounting Information Systems, 2, 149-168.

EVANS, J.H.; PATTON, J.M. (1987): "Signalling and monitoring in public sector accounting”, Journal of Accounting Research, 25, Suppl, 130-158.

FISCHER, M.; GORDON, T. (1991): "Towards Better Annual Reports for Colleges and Universities”, Government Accountants' Journal, 40 (2), 35-44.

FISCHER, M.; GORDON, T.; GREENLEE, J.; KEATING, E.K. (2004): "Measuring Operations: an Analysis of Us Private Colleges and Universities", Financial Accountability \& Management, 20 (2), 129-151.

FRIEDMAN, J.; SILBERMAN, J. (2003): "University technology transfer: do incentives, management, and location matter?", Journal of Technology Transfer, 28, 17-30

GALLEGO-ÁLVAREZ, I.; GARCÍA-SÁNCHEZ, I.M.; RODRÍGUEZ-DOMÍNGUEZ, L. (2008): "Voluntary and Compulsory Information Disclosed Online: Effect of Industry Concentration and other Explanatory Factors The presentation of financial information at corporate Web sites", Online Information Review, 32 (5), 596-622.

GANDÍA, J.L. (2001): La divulgación de información financiera en la era digital, Asociación Española de Contabilidad y Administración de Empresas, Madrid.

GANDÍA, J.L.; ANDRÉS, T. (2005): e-Gobierno corporativo y transparencia informativa en las sociedades cotizadas españolas: un estudio empírico, Monografías no.8, Dirección de Estudios y Estadísticas, Comisión Nacional del Mercado de Valores.

GARCÍA-MECA, E.; MARTÍNEZ, I. (2004): "Divulgación voluntaria de información empresarial: Índices de Revelación”, Partida Doble, 157, 66-77. 
GINER, B. (1995): La divulgación de información financiera: una investigación empírica, Instituto de Contabilidad y Auditoría de Cuentas, Madrid.

GINER, B. (1997): "The influence of company characteristics and accounting regulation on information disclosed by Spanish firms", European Accounting Review, 6 (1), 45-68.

GINER, B.; ARCE, M.; CERVERA, N.; RUIZ. A. (2003): "Incentivos para la divulgación voluntaria de información: evidencia empírica sobre la información segmentada", Revista Europea de Dirección y Economía de la Empresa, 12 (4), 69-86.

GORDON, T.; FISCHER, M.; MALONE, D.; TOWER, G. (1997): A Comparative Empirical Examination of Extent of Disclosure by Private and Public Colleges and Universities in the United States, Paper presented in Forum at the 1997 Annual Meeting of the American Accounting Association in Dallas.

GORDON, T., FISCHER, M., MALONE, D.; TOWER, G. (2002): “A Comparative Empirical Examination of Extent of Disclosure by Private and Public Colleges and Universities in the United States", Journal of Accounting and Public Policy, 21, 235-275.

GOVERNMENT ACCOUNTING STANDARS BOARD (GASB) (1999): Statement $\mathrm{n}^{\circ}$ 35, Basic financial statements and management discussion and analysis for public colleges and universities (November). GASB, Norwalk, CT.

GRAY, G.; DEBRECENY, R. (1997): Corporate reporting on the Internet: opportunities and challenges, paper presented at the Seventh Asian-pacific Conference on International Accounting Issues, Bangkok.

GUL, F.A.; LEUNG, S. (2004): "Board leadership, outside directors' expertise and voluntary corporate disclosures", Journal of Accounting and Public Policy, 23, 351-379.

HECHINGER (2006): "Politics \& Economics: House Endorses Fuller Disclosure on College Costs", Wall Street Journal, Mar 31, 2006

HEDLIN, P. (1999): "The Internet as a vehicle for investor relations: the Swedish case", European Accounting Review, 8 (2), p. 373-381.

IHATOR, A. (2001): "Corporate Communication: Challenges and Opportunities in a Digital World”, Public Relations Quarterly, 46, 15-18

INGRAM, R.T. (1998): "Sweeping Reform of Public Trusteeship?. Yes, it's Time for Change”, Trusteeship, 6 (3), 11-15. 
JUSTICE, J.B.; MELITSKI, J.; SMITH, D.L. (2006): "E-Government as an instrument of fiscal accountability and responsiveness: Do the best practitioners employ the best practices?", American Review of Public Administration, 36 (3), 301-322.

KASS, J. (2005): "Higher-education foundations facing new scrutiny", Boston Globe, April 1, 2005

KHANNA, T.; PALEPU, K.G.; SRINIVASAN, S. (2004): "Disclosure practices of foreign companies interacting with U.S. markets", Journal of Accounting Research, 42 (2), 474-508.

KURTENBACH, J.M.; ROBERTS, R.W. (1994): "Public Sector Research in Accounting. A Review and Synthesis", Public Budgeting and Financial Management, 6 (2), 216-253.

LARRÁN, M.; GINER, B. (2002): "The use of the Internet for corporate reporting by Spanish companies", The International Journal of Digital Accounting Research, 2 .(1), 53-82.

LASWAD, F.; FISHER, R.; OYELERE, P. (2005): "Determinants of voluntary Internet financial reporting by local government authorities", Journal of Accounting and Public Policy, 24, 101-121.

LAWRENCE, S.; GILES, C.L. (1999): "Accessibility of information on the web", Nature, 8, 107-109.

LEYDESDORFF, L.; MEYER, M. (2003): "The triple helix of university-industrygovernment relations", Scientometrics, 58 (2), 191-203.

LIM, S.; MATOLCSY, Z.; CHOW. D. (2007): "The Association between Board Composition and Different Types of Voluntary Disclosure", European Accounting Review, 16, 555-583.

MANSFIELD, E. (1995): "Academic research underlying industrial innovations: sources, characteristics, and financing", The Review of Economics and Statistics, 77 (1), 55-65.

MARSTON, C.; POLEI, A. (2004): "Corporate reporting on the Internet by German companies”, International Journal of Accounting Information Systems, 5 (3), 285-311.

MIDDLETON, I.; MCCONNELL, M.; DAVIDSON, G. (1999): "Presenting a model for the structure and content of a university World Wide Web site", Journal of Information Science, 25 (3), 219-227. 
MOISAN, L.J. (1992): "Because That's where the Money is", AGB Reports, 34 (5), 8-12. MURIAS, P.; de MIGUEL, J.C.; RODRÍGUEZ, D. (2008): “A Composite Indicator for University Quality Assesment: The Case of Spanish Higher Education System?", Social Indicator Research, 89 (1), 129-146.

NELSON, M.; BANKS, W.; FISHER, J. (2003): "Improved Accountability Disclosures by Canadian Universities", Canadian Accounting Perspectives, 2 (1), 77-107.

NELSON, M.; FISHER, J.; TOWER, G.;; BANKS, W. (1997): "University reporting: Looking for the facts", Australian Accountant, 67 (9), 40-43.

OLSINA, L.; GODOY, D.; LAFUENTE, G.J.; ROSI, G. (1999): Specifying Quality Characteristics and Attributes for Web Sites, Paper presented at the First ICSE Workshop on Web Engineering, Los Angeles, CA: USA.

ORTIZ, E.; CLAVEL, J.G. (2006): "Índices de revelación de información: Una propuesta de mejora de la metodología. Aplicación a la información sobre recursos humanos incluida en los Informes 20F”, Revista Española de Financiación y Contabilidad, 35 (128), 87-113.

OYELERE, P.; LASWAD, F.; FISHER, R. (2003): "Determinants of Internet financial reporting by New Zealand companies", Journal of International Financial Management and Accounting, 14 (1), 26-63.

PAISEY, C.; PAISEY, N.J. (2006): “And they all lived happily ever after? Exploring the possibilities of mobilising the Internet to promote a more enabling accounting for occupational pension schemes", Accounting, Auditing \& Accountability Journal, 19 (5), 719-758.

PETRAVICK, S.; GILLET, J. (1998): "Distributing earnings reports on the Internet", Management Accounting, 80, 54-56.

PETTERSEN, I-J.; SOLSTAD, E. (2007): "The Role of Accounting Information in a Reforming Area: a Study of Higher Education Institutions", Financial Accountability \& Management, 23 (2), 133-154.

PINA, V.; TORRES, L.; ROYO, S. (2007): IS E-government leading global convergence towards accountable governments?. Paper presented at the XIV Congress of AECA. 1921 September: Valencia, Spain. 
PIRCHEGGER, B.; WAGENHOFER, A. (1999): "Financial information on the Internet: A survey of the homepages of Austrian companies", European Accounting Review, 8, (2), 383-395.

PRENCIPE, A. (2004): "Proprietary costs and determinants of voluntary segment disclosure: evidence from Italian listed companies", European Accounting Review, 13 (2), 319-340.

RAFFOURNIER, B. (1995): "The determinants of voluntary financial disclosure by Swiss listed companies”, European Accounting Review, 4 (2), 261-280.

SHANE, S. (2004): Academic Entrepreneurship, University Spinoffs and Wealth Creation. Edward Elgar, Cheltenham, UK.

SMITH, A.; THELWALL, M. (2002): "Web impact factors for Australasian universities", Scientometrics, 5 (3), 362-380.

SPORN, B. (1999): Current issues and future priorities for European higher education systems, in Altbach, P.G. and Peterson, P.M. (ed.), Higher Education in the 21st Century: Global Challenge and National Response, New York: Institute of International Education, Report No. 29, 67-77.

TORRES, L.; PINA, V.; ROYO, S. (2005): "E-government and the transformation of public administrations in EU countries: Beyond NPM or just a second wave of reforms?", Online Information Review, 29 (5), 531-553.

XIAO, J.Z.; YANG, H.; CHOW, Ch.W. (2004): "The determinants and characteristics of voluntary Internet-based disclosures by listed Chinese companies", Journal of Accounting and Public Policy, 23 (3), 191-225.

ZIMMERMAN, J.L. (1977): "The municipal accounting maze: An analysis of political incentives", Journal of Accounting Research, 15, Suppl.; 107-144. 